\title{
Nuclear receptor regulation of stemness and stem cell differentiation
}

\author{
Yangsik Jeong and David J. Mangelsdorf ${ }^{1}$ \\ Department of Pharmacology and \\ Howard Hughes Medical Institute \\ University of Texas Southwestern Medical Center \\ Texas 75390, U.S.A. \\ ${ }^{1}$ Corresponding author: Tel, 1-214-645-5957; \\ Fax, 1-214-645-5969; E-mail, davo.mango@utsouthwestern.edu \\ DOI 10.3858/emm.2009.41.8.091
}

Accepted 5 August 2009

Abbreviations: AR, androgen receptor; C/EBP, CCAAT enhancer binding protein; COUP-TF, chicken ovalbumin upstream promoter transcription factor; DAX1, dosage-sensitive sex reversal-adrenal hypoplasia congenita critical region on the $\mathrm{X}$ chromosome, gene 1; ER, estrogen receptor; ERR, estrogen-related receptor; ESC, embryonic stem cell; ETO/MTG, eight twenty-one/myeloid translocation gene; GCNF, germ cell nuclear factor; GR, glucocorticoid receptor; GSK3, glycogen synthase kinase 3; HSC, hematopoietic stem cell; iPS, induced pluripotent stem cell; LRH1, liver receptor homolog 1; LXR, liver $X$ receptor; mdDA, meso-diencephalic dopaminergic neuron; MSC, mesenchymal stem cell; NGFI-B, nerve growth factor induced gene B; NOR1, neuron-derived orphan receptor 1; NR, nuclear receptor; NSC, neural stem cell; NURR1, nur-related factor 1; PPAR, peroxisome proliferator-activated receptor; QPCR, quantitative real-time PCR; RAR, retinoic acid receptor; RXR, retinoid X receptor; TCF-4, T-cell nuclear factor 4; TLX, tailless homolog orphan receptor; TR, testicular orphan receptor; VDR, vitamin D receptor

\begin{abstract}
Stem cells include a diverse number of toti-, pluri-, and multi-potent cells that play important roles in cellular genesis and differentiation, tissue development, and organogenesis. Genetic regulation involving various transcription factors results in the self-renewal and differentiation properties of stem cells. The nuclear receptor (NR) superfamily is composed of $\mathbf{4 8}$ ligand-activated transcription factors involved in diverse physiological functions such as metabolism, development, and reproduction. Increasing evidence shows that certain NRs function in regulating stemness or differentiation of embryonic stem (ES) cells and tissue-specific adult stem cells. Here, we review the role of the NR superfamily in various aspects of stem cell biology, including their regulation of stemness, forward- and
\end{abstract}

trans-differentiation events; reprogramming of terminally differentiated cells; and interspecies differences. These studies provide insights into the therapeutic potential of the NR superfamily in stem cell therapy and in treating stem cell-associated diseases (e.g., cancer stem cell).

Keywords: cell transdifferentiation; embryonic stem cells; pluripotent stem cells; receptors, cytoplasmic and nuclear; stem cells

\section{Introduction}

Stem cells have physiologically unique features including self-renewal and maintenance of unspecialized properties that can be manipulated in the presence of certain stimuli. These distinct traits distinguish stem cells from specialized, determined cell types. In general, stem cells are classified into two major types, embryonic stem (ES) cells and adult or somatic stem cells. ES cells are primitive cells derived from various embryonic or fetal stages of development and include three sub-classes: 1) Fertilized embryonic stem cells that are totipotent cells from the fertilized egg to the eight cell stage, 2) blastocyst embryonic stem cells that are pluripotent cells derived from the inner cell mass, and 3 ) fetal stem cells that are pluripotent cells derived from the fetus (about 8 weeks) itself or multipotent cells from umbilical cord blood. Since the use of embryonic and fetal derived stem cells is controversial in many countries, multi-potent umbilical cord blood cells or induced pluripotent stem (iPS) cells (discussed below) are of interest for research purposes and for their clinical therapeutic potential.

Adult stem cells are undifferentiated cells found in differentiated niches. These niches provide the proper environmental signals to maintain stemness or induce differentiation of stem cells. Lineage-specific progenitors are mostly tissue-specific stem cells that include mesenchymal stem cells (MSCs) for adipose, muscle, or bone; hematopoietic stem cells (HSCs) for blood or bone remodeling; and neural stem cells (NSCs) for the nervous system. Since ethical concerns limit the therapeutic applicability of ES cells in humans, autograft therapy using self-stem cells has been pursued to treat diverse categories of diseases including neurologic 
disorders and heart disease in private clinics in many countries (Lau et al., 2008; Kiatpongsan and Sipp, 2009). However, the utility of this approach, which is based on transdifferentiation of adult stem cells into functional cell types, is uncertain since the efficacy of transdifferentiation events is quite low (Wagers et al., 2002; Roybon et al., 2006; Xu et al., 2009). In this regard, iPS cells are rather promising for clinical applicability. Seminal studies on iPS demonstrated that somatic cells can be genetically reprogrammed by a defined set of core transcription factors - Oct3/4, Sox2, Klf4, c-Myc, Nanog, and Lin-28 whose expression is sufficient for the reverse-differentiation of fibroblasts into iPS cells (Takahashi and Yamanaka, 2006; Okita et al., 2007; Takahashi et al., 2007). While safety issues caused by vector integration still prevent the clinical application of iPS cells, the development of non-integrating systems or a precise excision system for integrated vectors is showing promise for resolving this essential issue (Stadtfeld et al., 2008b; Kaji et al., 2009; Woltjen et al., 2009; Yu et al.,

Table 1. Summary of NR function in stem cells.

\begin{tabular}{|c|c|c|c|}
\hline \multicolumn{2}{|c|}{ Nuclear receptor } & \multirow[b]{2}{*}{ Function } & \multirow[b]{2}{*}{ References } \\
\hline $\begin{array}{l}\text { Common } \\
\text { abbreviation }\end{array}$ & $\begin{array}{l}\mathrm{NRNC}^{\dagger} \\
\text { abbreviation }\end{array}$ & & \\
\hline \multirow[t]{2}{*}{ AR } & NR3C4 & Adipogenesis & (Singh et al., 2006; Gupta V et al., 2008) \\
\hline & & Myogenesis & (Singh et al., 2003, 2009) \\
\hline \multirow{2}{*}{ COUP-TF $\beta$} & NR2F2 & Adipogenesis & (Xu et al., 2008; Li et al., 2009) \\
\hline & & Myogenesis & (Bailey et al., 1998; Lee et al., 2004) \\
\hline DAX-1 & NR0B1 & ES cell stemness & (Wang et al., 2006; Kim et al., 2008; Sun et al., 2008; Xie et al., 2009) \\
\hline $\mathrm{ER} \beta$ & NR3A2 & NSC differentiation & (Wang et al., 2001; Brannvall et al., 2002; Kishi et al., 2005) \\
\hline \multirow[t]{2}{*}{$\mathrm{ERR} \beta$} & NR3B2 & ES cell stemness & (Zhou et al., 2007; van den Berg et al., 2008; Zhang X et al., 2008) \\
\hline & & Induce iPS cells & (Gu et al., 2005a; Feng et al., 2009) \\
\hline \multirow[t]{2}{*}{ GCNF } & NR6A1 & ES cell differentiation & (Gu et al., 2005b) \\
\hline & & Neuronal differentiation & (Sattler et al., 2004; Chung et al., 2006; Akamatsu et al., 2009) \\
\hline \multirow[t]{3}{*}{ GR } & NR3C1 & Adipogenesis & (Tomlinson et al., 2006) \\
\hline & & Chondrogenesis & (Derfoul et al., 2006) \\
\hline & & NSC proliferation & (Mayer et al., 2006; Sundberg et al., 2006) \\
\hline $\mathrm{LRH}-1$ & NR5A2 & ES cell stemness & (Gu et al., 2005a) \\
\hline NGFI-B & NR4A1 & Adiopgenesis & (Au et al., 2008; Chao et al., 2008) \\
\hline NOR1 & NR4A3 & & \\
\hline NURR1 & NR4A2 & Neuronal differentiation & $\begin{array}{l}\text { (Wallen-Mackenzie et al., 2003; Perlmann and Wallen-Mackenzie, } \\
\text { 2004; Blin et al., 2008; Jacobs et al., 2009) }\end{array}$ \\
\hline PPAR $\delta$ & NR1C2 & Transdifferentiation & (Holst et al., 2003; Wang et al., 2004; Teunissen et al., 2007) \\
\hline \multirow[t]{5}{*}{ PPAR } & NR1C3 & Adipogenesis & $\begin{array}{l}\text { (Tontonoz et al., 1994; Hu et al., 1995; Fu et al., 2005; Crossno et } \\
\text { al., 2006; Yu et al., 2006; Seale et al., 2008; Tang et al., 2008; } \\
\text { Walkey and Spiegelman, 2008) }\end{array}$ \\
\hline & & Osteoblastogenesis & (Akune et al., 2004; Shockley et al., 2009) \\
\hline & & Osteoclastogenesis & (Wan et al., 2007) \\
\hline & & $\begin{array}{l}\text { Neuronal proliferation and } \\
\text { differentiation }\end{array}$ & (Park et al., 2004; Wada et al., 2006) \\
\hline & & Transdifferentiation & $\begin{array}{l}\text { (Holst et al., 2003; Crossno et al., 2006; Yu et al., 2006; Seale et al., } \\
\text { 2008) }\end{array}$ \\
\hline \multirow[t]{2}{*}{$\mathrm{RAR} \alpha, \beta$} & NR1B1, 2 & Chondrogenesis & (Kafienah et al., 2007) \\
\hline & & NSC differentiation & (Jepsen et al., 2007; Goncalves et al., 2009) \\
\hline RAR $\beta$ & NR1B2 & Adipogenesis & (Monteiro et al., 2009) \\
\hline $\mathrm{RAR} \gamma$ & NR1B3 & HSC repopulation & (Purton et al., 2006; Safi et al., 2009) \\
\hline $\mathrm{RXR} \alpha, \beta, \gamma$ & NR2B1, 2, 3 & NSC proliferation (?) & (Aberg et al., 2008; Tay et al., 2008b; Kim M et al., 2009) \\
\hline TLX & NR2E1 & Neurogenesis & (Shi et al., 2004, 2008; Liu et al., 2008; Zhang CL et al., 2008) \\
\hline $\operatorname{TR} \alpha$ & NR1A1 & NSC proliferation & (Lemkine et al., 2005) \\
\hline TR2 & $\mathrm{NR} 2 \mathrm{C} 1$ & ES cell differentiation & (Gupta P et al., 2008) \\
\hline \multirow[t]{3}{*}{ VDR } & NR111 & Adipogenesis & (Blumberg et al., 2006; Kong and Li, 2006) \\
\hline & & Chondrogenesis & (Tsonis, 1991; Akiyama et al., 1996) \\
\hline & & Osteoclastogenesis & (Masuyama et al., 2006) \\
\hline
\end{tabular}

${ }^{\dagger}$ Indicates Nuclear Receptor Nomenclature Committee. 
2009). Recently, multiple iPS cells have been established from various sources of somatic cells, including fibroblasts, peripheral blood cells, pancreatic beta cells, hepatocytes, gastric epithelial cells, and adult neural stem cells by genetically introducing the newly defined core set of stem cell transcription factors (Aoi et al., 2008; Park et al., 2008; Stadtfeld et al., 2008a; Kim JB et al., 2009; Loh et al., 2009). These studies suggest that transcriptional control is a pivotal step in regulating stemness, differentiation, and genetic reprogramming of the differentiated cells back into cellular stemness.
The nuclear receptor (NR) superfamily consists of 48 members of mostly ligand-activated transcription factors involved in diverse physiological events including regulation of stem cell differentiation (Mangelsdorf et al., 1995; Germain et al., 2006; Mullen et al., 2007). Not only are NRs involved in the pathway of tissue-specific stem cell regulation, but certain NRs also play crucial roles in maintaining ES cells in cooperation with Oct3/4 and Nanog. Although some NRs, individually or in small group, have been studied in the context of developmental and stem cell biology (Mullen et al.,

\section{A}

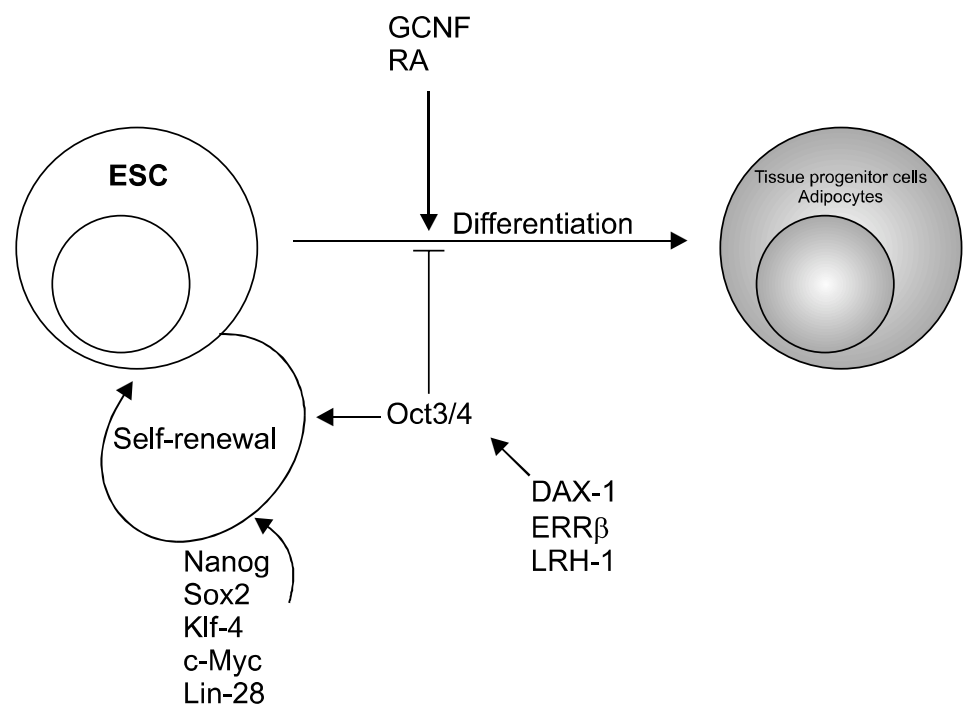

B

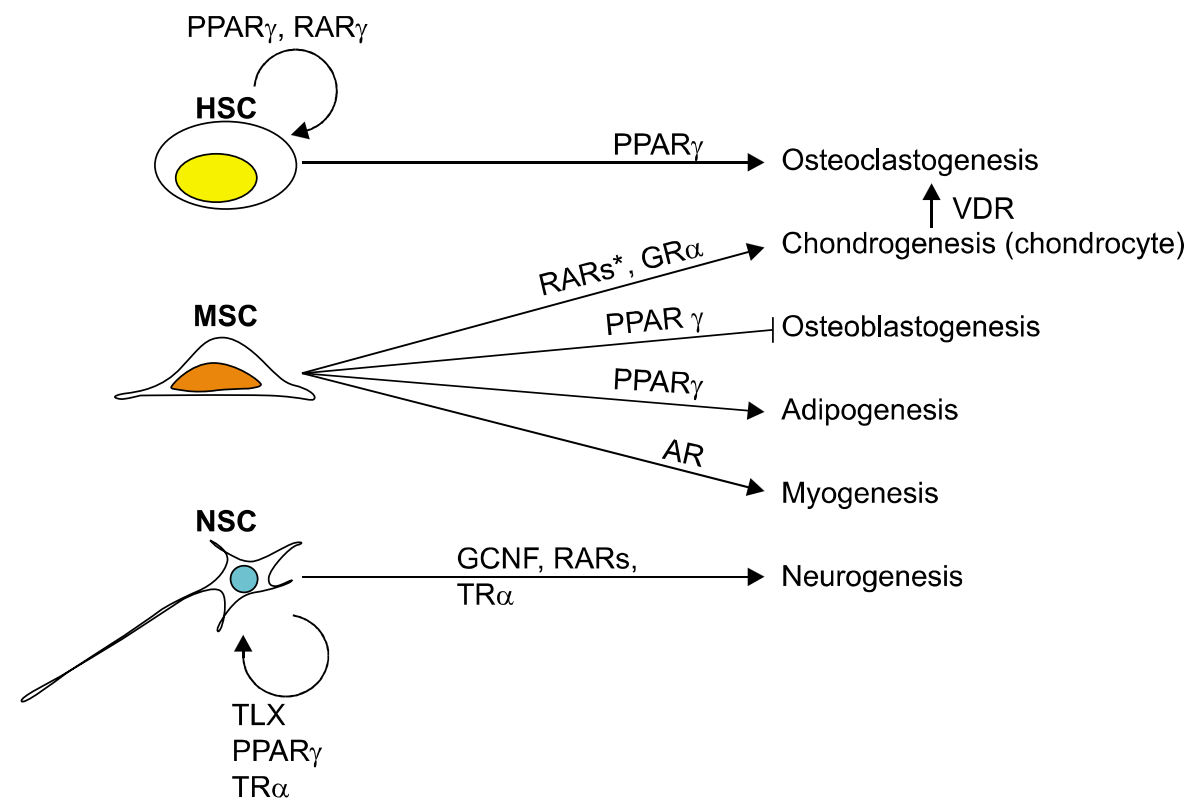

Figure 1. Schematic diagram for NR actions on stem cells. (A) NRs regulating pluripotency of ES cells. GCNF and RARs are involved in inducing ES cell differentiations. DAX-1, ERR $\beta$, and LRH-1 maintain stemness of ES cells by inducing Oct $3 / 4$ expression. (B) NRs involved in lineage-specification of adult stem cells. Subsets of NRs are involved in guiding MSC differentiation into diverse physiological lineage of cell types. HSC, hematopoietic stem cell; MSC, mesenchymal stem cell; NSC, neural stem cell; RA, retinoic acid. *indicates NR repressing MSC differentiation into chondrocytes. 
2007; Duester, 2008; Niederreither and Dolle, 2008; Shi et al., 2008), a comprehensive overview of the NR superfamily in stem cell biology is lacking. Here we focus on reviewing the roles of those NRs that are known to be involved in adult and embryonic stem cell biology. Specific information related to these NRs is summarized in Table 1. A goal of this review is to provide insight into the potential use of NR superfamily members as both research tools and therapeutic targets for understanding the biology and clinical utility of embryonic, adult, and induced pluripotent stem cells. This overview also highlights interspecies differences (mouse vs. human) with respect to the mRNA expression profile for a subset of NRs in the early differentiation process of embryonic stem cells.

\section{NRs in adult mesenchymal stem cells}

\section{Adipogenesis}

Adipogenesis is an atypical developmental process in that it occurs postnatally, leading to the formation of fat, which plays important roles in regulating energy metabolism and as an endocrine organ (Lefterova and Lazar, 2009). This distinctive developmental process occurs when a highly specialized niche of mesenchymal stem cells become committed preadipocytes that differentiate into adipose tissue upon proadipogenic stimuli (Figure $1 \mathrm{~A}$ and $1 \mathrm{~B})$. Recently, resident adipogenic progenitor cells have been identified in adipose vasculature using a transgenic mouse model expressing green fluorescence protein under the control of the peroxisome proliferator-activated receptor gamma (PPAR $\gamma$ ) promoter, which was then utilized for lineage tracing analyses (Tang et al., 2008). Multiple groups have shown that PPAR $\gamma$ is required for normal adipogenesis and induces adipogenic transdifferentiation from non-adipogenic cell types including primary myoblasts and bone marrow-derived progenitor cells, along with terminal differentiation of preadipocyte 3T3-L1 cell lines into adipocytes (Tontonoz et al., 1994; Hu et al., 1995; Crossno et al., 2006; Yu et al., 2006; Seale et al., 2008). Interestingly, Walkey and Spiegelman et al. (2008) found that the ligand-binding domain of PPAR $\gamma$ is not required for adipogenesis (Walkey and Spegielman, 2008). A mutant PPAR $\gamma$ (Q286P), which lacks ligand binding capability, was shown to be comparable to the wild type PPAR $\gamma$ for generating fat pads in mice when the genetically manipulated fibroblasts were subcutaneously injected, suggesting a ligand-independent form of adipogenesis (Walkey and Spiegelman, 2008). It will be interesting to know if adipogenesis from non-adipogenic cell types (e.g., MSC and primary myoblasts) is also independent of ligand binding to PPAR $\gamma$. Retinoic acid receptor beta $(R A R \beta)$ is also known to be involved in retinoic acid (RA) induced adipogenesis of differentiating mES cells (Figure 1A), which require active glycogen synthase kinase 3 (GSK3) (Monteiro et al., 2009). GSK3 inhibits activation of the Wnt pathway, which leads to terminal differentiation of preadipocytes into adipocytes (Ross et al., 2000; Bennett et al., 2002; Christodoulides et al., 2006). However, it is of interest to note that the inhibition of the Wnt pathway is not necessary for RARß/active GSK3-induced adipogenic differentiation of mES cells. Treatment with the synthetic glucocorticoid, dexamethasone, is pro-adipogenic in the differentiation of both human and mouse preadipocyte models (Tomlinson et al., 2006). Indeed, RAR $\beta$ and GR are constitutively expressed during differentiation process of $3 T 3-\mathrm{L} 1$ cells (Fu et al., 2005). This indicates that the control of ligand availability may be more crucial than regulation of receptor expression for certain NRs in adipogenic regulation.

Several NRs are also known for their ability to antagonize adipogenic differentiation, including androgen receptor $(A R)$, chicken ovalbumin upstream promoter transcription factor (COUP-TF) $\beta$, vitamin $D$ receptor (VDR), and the NR4A subfamily members known as nerve growth factor induced gene $B$ (NGFI-B), neuron-derived orphan receptor 1 (NOR1), and nur-related factor 1 (NURR1). A role for these NRs during adipogenesis was first revealed by a comprehensive survey of their distinct patterns of expression during the 3T3-L1 differentiation (Fu et al., 2005). Subsequently, AR expression was shown to inhibit adipogenic differentiation of human mesenchymal stem cells (MSC) and 3T3L1 cells in the presence of testosterone, a physiological ligand for AR (Singh et al., 2006). Similarly, recent studies characterized COUP-TF $\beta$ as a potent suppressor of adipogenesis, where it plays an important role in developing white adipose tissue through its inhibition of Wnt signaling pathway (Xu et al., 2008; Li et al., 2009). Both AR and COUP-TF $\beta$ expression are also relevant to myogenic differentiation. VDR activation inhibits adipogenic differentiation by suppressing the expression of pro-adipogenic genes such as CCAAT enhancer binding protein (C/EBP) $\alpha$, $\operatorname{PPAR} \gamma$, and sterol regulatory element binding protein 1 in mouse 3T3-L1 preadipocyte cells (Kong and Li, 2006). Similarly, Blumberg et al. (2006) found that VDR activation inhibits C/EBP $\beta$ expression and induces the expression of eight twentyone/myeloid translocation gene (ETO/MTG), which further inhibits the action of C/EBP $\beta$ (Blumberg et al., 2006). In addition, VDR activation inhibits 
adipogenic differentiation of murine bone marrow stromal cells by suppressing the expression of dickkopf-1 and secreted frizzled-related protein 2, which are negative regulators for the canonical Wnt signaling pathway (Cianferotti and Demay, 2007). Recent studies revealed that NR4A members inhibit adipocyte differentiation, and interestingly, this NR4A-mediated adipogenic inhibition could not be reversed by the overexpression of PPAR $\gamma$ (Au et al., 2008; Chao et al., 2008).

The NR expression profile study mentioned above identified numerous other NRs previously uncharacterized in adipogenesis (Fu et al., 2005). Included in this list were reverse (rev)-erb $\alpha$ and rev-erb $\beta$, retinoic acid-related orphan receptor $\gamma$, COUP-TF $\alpha$ and $\gamma$, germ cell nuclear factor (GCNF), retinoid $X$ receptor $\beta$, and testicular orphan receptor (TR) 2 and 4 (Fu et al., 2005). The role of these NRs in modulating adipogenesis should be an interesting avenue of future investigation.

\section{Myogenesis}

As might be expected from its anabolic role in development, AR has been implicated in muscle differentiation. Dihydrotestosterone treatment promoted myogenic differentiation (Singh et al., 2003; Gupta V et al., 2008). These effects of testosterone and dihydrotestosterone on myogenesis and adipogenesis were antagonized by the anti-androgen, bicalutamide (Singh et al., 2003) (Figure 1B). Further investigation of AR-mediated myogenic differentiation revealed a molecular mechanism by which liganded AR interacts with beta-catenin and T-cell factor 4 (TCF-4), leading to activation of the myogenic differentiation program in multipotent $\mathrm{C} 3 \mathrm{H}$ 10T1/2 cells (Shang et al., 2007; Singh et al., 2009). This suggests that AR plays an important role in fate determination of MSCs both in adipogenic and myogenic differentiation.

COUP-TF $\beta$ is known to be important in skeletal muscle development (Lee et al., 2004). This orphan NR inhibits myogenic differentiation of mouse C2 myogenic cells by decreasing MyoD expression, which is required for myogenic differentiation (Bailey et al., 1998). Similarly, decreased expression of the myogenic determination factor myogenin is observed in COUP-TF $\beta$ mutant embryos compared to wild type littermates (Lee et al., 2004). Thus, COUP-TF $\beta$ appears to play an important role in maintaining undifferentiated myogenic cells by inhibiting myogenic differentiation (Lee et al., 2004).

\section{Chondrogenesis}

Chondrogenesis is a process that forms cartilage from mesenchymal tissues and also involves multiple NR functions as shown in Figure 1B (Tsonis, 1991; Akiyama et al., 1996; Derfoul et al., 2006; Kafienah et al., 2007). While VDR activation induces chondrogenesis in cultures of chick embryo limb bud mesenchymal cells (Tsonis, 1991), treatment with VDR agonists inhibits cell growth and chondrogenesis of a clonal chondrogenic ATDC5 cells (Akiyama et al., 1996). This suggests that VDR modulates chondrogenic differentiation in a tissue specific manner. Glucocorticoid treatment induced chondrogenic differentiation from human bone marrow-derived mesenchymal stem cells (Derfoul et al., 2006). Functional inhibition of RAR $\alpha$ and RAR $\beta$ using synthetic antagonists resulted in chondrogenesis of human bone marrow mesenchymal population in 3D matrix culture (Kafienah et al., 2007). Interestingly, the RAR-mediated chondrogenic regulation is independent of the canonical chondrogenic pathway involving sry-related high-mobility-group box (Sox) transcription factor SOX9 (Kafienah et al., 2007).

\section{NRs in hematopoietic stem cells}

\section{Osteoclastogenesis}

NRs are known for their role in the differentiation of bone marrow-derived hematopoietic stem cells (HSCs) and for the HSC repopulation (Figure 1B). Long term treatment of rosiglitazone, a PPAR $\gamma$ agonist, is known to increase circulating bone marrow-derived mesenchymal and hematopoietic progenitor cells (Crossno et al., 2006). This PPAR $\gamma$ agonist treatment seems to mobilize MSC differentiation into a more adipogenic pathway, which results in reduced osteoblast differentiation (Akune et al., 2004; Crossno et al., 2006; Shockleyet al., 2009). On the other hand, the increased population of hematopoietic progenitors by PPAR $\gamma$ activation appears to induce osteoclastogenesis. Wan et al. (2007) recently demonstrated that osteoclast differentiation required PPAR $\gamma$ activation to directly regulate expression of $c$-fos, an important mediator in osteoclastogenesis (Figure 1B) (Wan et al., 2007). The authors also provided evidence of osteoclastogenesis occurring from the hematopoietic rather than the mesenchymal lineage (Wan et al., 2007). Similarly, VDR signaling in chondrocytes was shown to promote osteoclastogenesis (Masuyama et al., 2006). In addition to being involved in HSC proliferation and osteoclastogenesis, PPAR $\gamma$ also directs lineage-specific differentiation of human monocytes into an anti-inflammatory M2 phenotype (Bouhlel et al., 2007). Furthermore, several studies have shown that the RA signaling 
pathway is involved in maintaining the HSC population (Purton et al., 2006; Safi et al., 2009). Interestingly, RAR gamma (RAR $\gamma$ ) null bone marrow lost its repopulating capacity, which resulted from a reduced HSC population and increased numbers of more differentiated sub-progenitor cells (Purton et al., 2006) (Figure 1B).

\section{NRs in neural stem cells}

\section{Neurogenesis}

To generate an expression atlas of the NR superfamily in adult mouse brain, the expression profile of all 49 mouse NRs has been investigated by quantitative and anatomical means using quantitative real-time PCR (QPCR) and in situ hybridization techniques in 104 brain regions (Gofflot et al., 2007). From this study, use of the in situ hybridization assay revealed that most of the NR members (36 out of 47 surveyed NRs) are expressed in the dentate gyrus, which is known to be associated with memory and neurogenesis in the hippocampal region. Some NRs (e.g., RARs, TLX, GCNF, TRs, PPAR $\gamma$, GR, ER, and NURR1) have been relatively well-studied in neurogenesis or neural differentiation. RA-mediated activation of both $\operatorname{RAR} \alpha$ and $\operatorname{RAR} \beta$ induces proliferation and differentiation of adult forebrain neural progenitor cells (Goncalves et al., 2009). Presumably 9-cis $\mathrm{RA}$, a known physiological ligand for the RXRs, is also involved in homeostatic regulation of neural progenitor cells through RXRs (Aberg et al., 2008). Of particular interest, expression of $R X R \gamma$ is restricted to the dentate gyrus granule cells (Gofflot et al., 2007), together with tailless homolog orphan receptor $(T L X)$ which will be discussed in detail for its functional role in neurogenesis (see below). From a mechanistic perspective, Jepsen et al. (2007) recently proposed a potential molecular mechanism by which RAR activation leads to neuronal differentiation of NSC by releasing the co-repressor SMRT from promoter of the histone demethylase JMJD3. De-repression of JMJD3 expression via the retinoid pathway induces activation of the neurogenic program (Jepsen et al., 2007).

Multiple studies have shown that GCNF is critical for neuronal differentiation (Sattler et al., 2004; Chung et al., 2006; Akamatsu et al., 2009). A recent study showed that fate determination of primitive NSCs into non-neural tissues and definitive NSCs involves GCNF repressing Oct3/4 expression by recruitment of complexes that methylate promoter DNA (Akamatsu et al., 2009) (see below).

TLX expression begins at embryonic day 8 and is high in adult brain but low in other peripheral tissues (Monaghan et al., 1995; Bookout et al., 2006). Further functional studies have shown that TLX plays an important role in maintaining proliferation and undifferentiated status of adult neural stem cells in the subventricular zone and the dentate gyrus of the adult brain (Shi et al., 2004; Liu et al., 2008). In a knock-out mouse model that specifically ablated TLX expression in the subventricular zone, Liu et al. identified astrocyte-like B cells as TLX expressing neural stem cells from GFAP positive glial cells in which TLX is required (Liu et al., 2008). Indeed, TLX regulates cell cycle progression during neural development in the embryonic brain (Li et al., 2008). Knock-out of TLX expression in neural stem cells of the ventricular zone results in a reduced size of the zone, due to induction of p21 and PTEN expression in the E14.5 mouse brain ( $\mathrm{Li}$ et al., 2008). In addition to the general function of TLX in maintaining embryonic and adult neural stem cells, TLX-positive neural stem cells have been shown to play physiologically important functions in learning and behavior (Zhang CL et al., 2008). The specific suppression of TLX expression in the adult mouse brain accompanied reduction of adult stem cell proliferation and resulted in impaired cognitive functions (e.g., spatial learning and memory) but not other behavior disorders such as locomotion activity and contextual fear conditioning. This suggests a distinctive role for $T L X$ in regulating neurogenesis into functionally specialized neurons.

Other NRs including PPAR $\gamma$, thyroid hormone receptors (TR), GR, estrogen receptors (ER), and NURR1 have also been shown to regulate neural stem cells. PPAR $\gamma$ is highly expressed in embryonic mouse brain and neural stem cells but not in adult mouse brain, suggesting a specific role of PPAR $\gamma$ in embryonic neural development. PPAR $\gamma$ activation appears to maintain NSC populations in embryonic mouse brains by inducing NSC proliferation through the epidermal growth factor receptor and ERK pathway, but inhibits NSC differentiation into neurons via STAT3 activation (Wada et al., 2006). However, treatment with the PPAR $\gamma$ agonist 15-deoxy-PGJ(2) promotes neuronal differentiation of PC12, a cell line derived from rat adrenal medulla. Interestingly, the same group of researchers proposed that 15-deoxy-PGJ(2) induced differentiation of embryonic midbrain cells into dopaminergic neuronal cells is JNK activation-dependent (Park et al., 2004). This neuronal differentiation of embryonic midbrain cells might be due to the pleiotropic effects of 15-deoxy-PGJ(2), even though it may also function as a physiological ligand of PPAR $\gamma$. 
Thyroid hormone is known to regulate hippocampal neurogenesis in the adult rat brain (Ambrogini et al., 2005; Desouza et al., 2005). Although both isoforms of thyroid hormone receptors ( $\alpha$ and $\beta$ ) are expressed in the dentate gyrus of adult brain, $\operatorname{TR} \alpha$, but not $\operatorname{TR} \beta$, was found to be expressed in nestin-positive neural progenitor cells in the subventricular zone. A further molecular study demonstrated that TR $\alpha$ is necessary for NSC proliferation (Lemkine et al., 2005). It has been reported that ER $\beta$ contributes to the normal neuronal development (Wang et al., 2001). Indeed, ER $\beta$ but not ER $\alpha$ is consistently expressed in the dentate gyrus of the mouse brain (Gofflot et al., 2007). In contrast to the previously discussed NRs, embryonic NSC proliferation is inhibited by GR activation, which induced ubiquitin-mediated cyclin D1 degradation (Sundberg et al., 2006). However, treatment with a GR antagonist reduced adult hippocampal neurogenesis (Mayer et al., 2006). Intriguingly, this suggests an opposing role for GR in regulating neurogenesis between the embryo and the adult. On the other hand, treatment with the ER agonist $17 \beta$-estradiol significantly decreased NSC proliferation in the adult rat brain but had marginal effects in embryos stimulated by EGF treatment, suggesting that $G R$ and $E R \beta$ might coordinate opposite events in the development of the embryo and the adult brains (Brannvall et al., 2002). Furthermore, $17 \beta$-estradiol treatment promoted terminal differentiation of human NSC into dopaminergic (DA) neurons (Kishi et al., 2005). Similarly, NURR1 is known to be responsible for terminal differentiation of meso-diencephalic (mdDA) neurons into a DA phenotype (Blin et al., 2008; Jacobs, et al., 2009). By signaling through heterodimeric partner RXRs, NURR1 plays an important role in developing dopaminergic neuron (Wallen-Mackenzie et al., 2003; Perlmann and Wallen-Mackenzie, 2004). The paired-like homeobox transcription factor Pitx3 replaces the SMRT-HDAC complex bound to NURR1, which sequentially induces de-repression of NURR target genes resulting in terminal differentiation of mdDA neurons (Jacobs et al., 2009).

\section{Transdifferentiation}

Beyond the lineage determination roles of the progenitor cells, some NRs function in the cellular plasticity that physiologically switches one cell type into another. For example, activation of PPAR $\delta$ induces switching of skeletal muscle fibers from type II (fast/glycolytic) to type I (slow/oxidative) (Wang et al., 2004). However, this particular NR seems to repress $\mathrm{C} 2 \mathrm{C} 12$ myoblast to myogenesis and transdifferentiation of cardiac fibroblast to myoblast. This myogenic repression potentiates adipogenic transdifferentiation during a subsequent treatment with PPAR ligand (Holst et al., 2003; Teunissen et al., 2007). Likewise, the function of PPAR $\gamma$ in transdifferentiation has been elucidated by identifying multilocular adipocytes differentiated from bone marrow-derived progenitor cells. To identify potential non-adipocyte progenitor cells differentiating into adipocytes, an in vivo transplantation technique was performed where whole bone marrow cells expressing green fluorescence protein from transgenic mice were transferred into wild type littermates, and put on a high-fat diet or treated with the PPAR $\gamma$ ligand, rosiglitazone (Crossno et al., 2006). This study revealed that bone marrow-derived circulating progenitor cells are differentiated into the multilocular adipocytes (Crossno et al., 2006). In addition, PPAR $\gamma$ induces transdifferentiation of myocytes into adipocytes (Holst et al., 2003; Yu et al., 2006). This could be due to the function of PRDM16 as a binding partner of PPAR $\gamma$. PRDM16 is involved in transdifferentiation between brown fat cells and skeletal myoblasts. PRDM16 mediated adipogenic conversion of primary myoblasts and $\mathrm{C} 2 \mathrm{C} 12$ cells is dependent on PPAR $\gamma$ activation, as demonstrated by Ppary-deficient fibroblasts which are unable to promote adipogenesis (Seale et al., 2008). Taken together, NRs play multiple roles in stem cell biology to maintain body homeostasis, including lineage specification, guiding terminal differentiation from tissue-specific progenitor cells, and fate switching into functionally different cell types.

\section{Embryonic stem cells}

Numerous studies on the factors involved in regulation of the pluripotent state of $E S$ cells have revealed a role for diverse transcription factors, including subsets of NRs. These NRs are mostly involved in regulating the expression or activity of primitive factors such as Oct3/4, Nanog, or KIf4, or vice versa, in ES cells upon stimulating with differentiation signals. For example, dosage-sensitive sex reversal-adrenal hypoplasia congenita critical region on the $X$ chromosome, gene 1 (DAX-1) is expressed in both human and mouse ES cells and was identified in the expanded transcriptional regulatory network of Nanog from a protein interaction study (Wang et al., 2006; Kim et al., 2008; Xie et al., 2009). Indeed, DAX-1 mRNA expression is regulated by Oct3/4 together with the STAT3 transcription factor (Sun et al., 2008), potentially contributing to the stemness of ES cells. Liver 
receptor homolog 1 (LRH1) is known to be co-localized with Oct $3 / 4$ in the inner cell mass and at the epiblast embryo stage of mouse. Bioinformatics analysis also identified LRH-1 in the genetic regulatory network maintaining the stemness of ES cells, together with Oct3/4, Sox2, and estrogen-related receptor beta (ERR $\beta$ ) (Gu et al., 2005a; Zhou et al., 2007). Gu et al. (2005a) showed that LRH-1 is required for maintaining Oct $3 / 4$ expression in ES cells and the epiblast stage of mouse embryo (Gu et al., 2005a). Along with LRH1, ERR $\beta$ also plays an essential role in maintaining mouse ES cells. Protein interaction of Nanog with ERR $\beta$ on the promoter of Oct $3 / 4$ induces its expression, which in turn is involved in DAX-1 expression with STAT3 (Sun et al., 2008; Zhang $X$ et al., 2008). In addition, a complex of ERR $\beta$ and Oct3/4 augments Nanog expression in mouse ES cells (van den Berg et al., 2008). More interestingly, the physiological function of ERR $\beta$ has been recently demonstrated in the reprogramming of mouse fibroblasts to iPS cells, where ERR $\beta$ is coordinately involved in conjunction with Oct3/4 and Sox2 (Feng et al., 2009).

In contrast to the functional roles of LRH1 and ERR $\beta$ in maintaining stemness of ES cells, GCNF and RARs promote ES cell differentiation. As mentioned earlier, RA treatment induces neural differentiation of ES cells, which further promotes neuronal maturation but suppresses neuronal cell proliferation (Kim M et al., 2009). A recent finding suggests a potential molecular mechanism of RA action by which the expression of a subset of microRNAs (e.g., miR-134, miR-296, and miR-470) is induced by treatment with a vitamin A derivative. These microRNAs subsequently target Nanog, Oct3/4, and Sox2 leading to translational inhibition in mouse ES cells (Tay et al., 2008a). Furthermore, RA-induced miR134 attenuates both Nanog and $\mathrm{LRH}-1$ expression, which are positive regulators for Oct3/4 expression, resulting in differentiation of ES cells into the ectodermic lineage (Tay et al., 2008b). Alternatively, RA-mediated Oct3/4 suppression involves sequential events of phosphorylation of TR2, recruitment of the nuclear protein PML, and sumoylation of TR2 that completes a complex that together recruits the co-repressor RIP140 to the Oct3/4 promoter (Park et al., 2007; Gupta P et al., 2008). Using $\mathrm{GCNF}^{-/-}$ES cells, it has been shown that GCNF is required for repressing pluripotent genes in the RA-induced ES cell differentiation (Gu et al., 2005b). This suggests that RA acting through RARs, and GCNF might coordinate neural differentiation of ES cells in development.

Functional studies of these individual NRs in ES cells opens the possibility that other NRs potentially could be associated with regulation of stem- ness and differentiation of ES cells. To address this question, expression profiling of the entire NR superfamily was systematically carried out using QPCR in human and mouse ES cells (Xie et al., 2009). This study surveyed not only basal expression in ES cells but also expression kinetics of the entire NR superfamily during embryoid body formation. Strikingly, a substantial interspecies difference in the expression patterns for many NRs was uncovered. Although this difference could be attributed to different culture conditions or cell growth rates for mouse vs. human ES cells, a separate study found no difference in global gene expression profiling of both human and mouse ES cells in different culture conditions (Ginis et al., 2004). Of particular interest, among the NRs discussed above (DAX-1, ERR $\beta, G C N F$, LRH-1, and RARs), only GCNF and RAR $\gamma$ exhibited similar patterns of expression in mouse and human undifferentiated ES cells and during early embryoid body formation. Surprisingly ERR $\beta$ was found to be exclusively expressed in mouse ES cells and during embryoid body formation process, but was not detectable in two human ES cell lines. In previous studies, both genetic and pharmacological mouse models have identified an important role for ERR $\beta$ in trophoblast differentiation and placenta formation (Luo et al., 1997; Tremblay et al., 2001; Chen and Nathans, 2007). Thus, of several fundamental differences between human and mouse in early development, placental formation is a prominent one that could be responsible at least partly for the interspecies differences observed in ERR $\beta$ expression (O'Rahilly and Muller, 1981; Hogan, 1994; Carter, 2007). Together, these studies suggest that subsets of NRs play a critical yet species-specific role in maintaining pluripotency and regulating differentiation of ES cells. How this should be taken into account when mouse models are used as a basis to understand human pathway will require further investigation.

\section{Perspective}

Although its clinical potential has been established under some circumstances, research on ES cells is accompanied by ethical concerns. The study on iPS cells initiated by Takahashi and Yamanaka (2006) has shed light on use of these cells as a potential alternative for ES cells (Takahashi and Yamanaka, 2006). While this work identified the core transcriptional factors necessary for reprogramming differentiated somatic cells into iPS, it also highlighted the importance of developing a safer delivery means for delivery of genetically expre- 
ssed materials (Stadtfeld et al., 2008b; Kaji et al., 2009; Woltjen et al., 2009; Yu et al., 2009). In addition to genetic strategies for acquiring iPS cells, pharmacological approaches are also conceivable. In this regard, certain members of the NR superfamily may be of particular interest because they are ligand-activated transcription factors involved in differentiation and maintenance of various stem cells types. The comparative profiling of NRs in human and mouse (where most ES cell work has been done) has also stressed the need for more studies comparing these two species. For example, a recent study has implicated an important role of ERR $\beta$ in inducing iPS cells from mouse fibroblasts (Feng et al., 2009). However, potential involvement of ERR $\beta$ in the genetic reprogramming process in human ES cells needs further investigation, since expression profiling showed no expression of ERR $\beta$ in human ES cells (Xie et al., 2009). It would also be important to know which NRs are involved in forward differentiation of ES cells and reverse differentiation of somatic cells. These questions will need to be addressed to define NR-associated transcriptional programs that maintain body cell homeostasis, and to direct the pharmacological utility of NR ligands in stem cell clinical applications.

\section{Acknowledgements}

We thank Drs. Elisabeth Martinez and Michael Peyton, and Angie Bookout for reading, discussion, and helpful comments. This work was supported by the Howard Hughes Medical Institute, Robert A. Welch Foundation (Grant I-1275), the National Institutes of Health (NURSA Grant U19DK62434), and the North and Central Texas Clinical and Translational Science Initiative (Grant UL1RR024982) from the National Center for Research Resources (NCRR).

\section{References}

Aberg E, Perlmann T, Olson L, Brene S. Running increases neurogenesis without retinoic acid receptor activation in the adult mouse dentate gyrus. Hippocampus 2008;18:785-92

Akamatsu W, DeVeale B, Okano H, Cooney AJ, van der Kooy D. Suppression of Oct4 by germ cell nuclear factor restricts pluripotency and promotes neural stem cell development in the early neural lineage. J Neurosci 2009;29:2113-24

Akiyama H, Hiraki Y, Shigeno C, Kohno H, Shukunami C, Tsuboyama T, Kasai R, Suzuki F, Konishi J, Nakamura T. 1 alpha,25-dihydroxyvitamin D3 inhibits cell growth and chondrogenesis of a clonal mouse EC cell line, ATDC5. J Bone Miner Res 1996;11:22-8

Akune T, Ohba S, Kamekura S, Yamaguchi M, Chung UI, Kubota N, Terauchi Y, Harada Y, Azuma Y, Nakamura K, Kadowaki T, Kawaguchi H. PPARgamma insufficiency enhances osteogenesis through osteoblast formation from bone marrow progenitors. J Clin Invest 2004;113:846-55

Ambrogini P, Cuppini R, Ferri P, Mancini C, Ciaroni S, Voci A, Gerdoni E, Gallo G. Thyroid hormones affect neurogenesis in the dentate gyrus of adult rat. Neuroendocrinology 2005;81:244-53

Aoi T, Yae K, Nakagawa M, Ichisaka T, Okita K, Takahashi K, Chiba T, Yamanaka S. Generation of pluripotent stem cells from adult mouse liver and stomach cells. Science 2008;321:699-702

Au WS, Payne VA, O'Rahilly S, Rochford JJ. The NR4A family of orphan nuclear receptors are not required for adipogenesis. Int J Obes (Lond) 2008;32:388-92

Bailey P, Sartorelli V, Hamamori Y, Muscat GE. The orphan nuclear receptor, COUP-TF II, inhibits myogenesis by post-transcriptional regulation of MyoD function: COUP-TF II directly interacts with p300 and myoD. Nucleic Acids Res 1998;26:5501-10

Bennett CN, Ross SE, Longo KA, Bajnok L, Hemati N, Johnson KW, Harrison SD, MacDougald OA. Regulation of Wnt signaling during adipogenesis. J Biol Chem 2002;277: 30998-1004

Blin M, Norton W, Bally-Cuif L, Vernier P. NR4A2 controls the differentiation of selective dopaminergic nuclei in the zebrafish brain. Mol Cell Neurosci 2008;39:592-604

Blumberg JM, Tzameli I, Astapova I, Lam FS, Flier JS, Hollenberg AN. Complex role of the vitamin D receptor and its ligand in adipogenesis in 3T3-L1 cells. J Biol Chem 2006;281:11205-13

Bookout AL, Jeong Y, Downes M, Yu RT, Evans RM, Mangelsdorf DJ. Anatomical profiling of nuclear receptor expression reveals a hierarchical transcriptional network. Cell 2006;126:789-99

Bouhlel MA, Derudas B, Rigamonti E, Dievart R, Brozek J, Haulon S, Zawadzki C, Jude B, Torpier G, Marx N, Staels B, Chinetti-Gbaguidi G. PPARgamma activation primes human monocytes into alternative M2 macrophages with anti-inflammatory properties. Cell Metab 2007;6:137-43

Brannvall K, Korhonen L, Lindholm D. Estrogen-receptordependent regulation of neural stem cell proliferation and differentiation. Mol Cell Neurosci 2002;21:512-20

Carter AM. Animal models of human placentation--a review. Placenta 2007;28 Suppl A:S41-7

Chao LC, Bensinger SJ, Villanueva CJ, Wroblewski K and Tontonoz P. Inhibition of adipocyte differentiation by Nur77, Nurr1, and Nor1. Mol Endocrinol 2008;22:2596-608

Chen J, Nathans J. Estrogen-related receptor beta/NR3B2 controls epithelial cell fate and endolymph production by the stria vascularis. Dev Cell 2007;13:325-37

Christodoulides C, Laudes M, Cawthorn WP, Schinner S, Soos M, O'Rahilly S, Sethi JK, Vidal-Puig A. The Wnt antagonist Dickkopf-1 and its receptors are coordinately regulated during early human adipogenesis. J Cell Sci 2006;119:2613-20

Chung AC, Xu X, Niederreither KA, Cooney AJ. Loss of 
orphan nuclear receptor GCNF function disrupts forebrain development and the establishment of the isthmic organizer. Dev Biol 2006;293:13-24

Cianferotti L, Demay MB. VDR-mediated inhibition of DKK1 and SFRP2 suppresses adipogenic differentiation of murine bone marrow stromal cells. J Cell Biochem 2007;101:80-8

Crossno JT, Jr., Majka SM, Grazia T, Gill RG, Klemm DJ. Rosiglitazone promotes development of a novel adipocyte population from bone marrow-derived circulating progenitor cells. J Clin Invest 2006;116:3220-8

Derfoul A, Perkins GL, Hall DJ, Tuan RS. Glucocorticoids promote chondrogenic differentiation of adult human mesenchymal stem cells by enhancing expression of cartilage extracellular matrix genes. Stem Cells 2006;24: 1487-95

Desouza LA, Ladiwala U, Daniel SM, Agashe S, Vaidya RA, Vaidya VA. Thyroid hormone regulates hippocampal neurogenesis in the adult rat brain. Mol Cell Neurosci 2005;29:414-26

Duester $\mathrm{G}$. Retinoic acid synthesis and signaling during early organogenesis. Cell 2008;134:921-31

Feng B, Jiang J, Kraus P, Ng JH, Heng JC, Chan YS, Yaw LP, Zhang W, Loh YH, Han J, Vega VB, Cacheux-Rataboul $\mathrm{V}$, Lim B, Lufkin T, Ng HH. Reprogramming of fibroblasts into induced pluripotent stem cells with orphan nuclear receptor Esrrb. Nat Cell Biol 2009;11:197-203

Fu M, Sun T, Bookout AL, Downes M, Yu RT, Evans RM, Mangelsdorf DJ. A Nuclear Receptor Atlas: 3T3-L1 adipogenesis. Mol Endocrinol 2005;19:2437-50

Germain P, Staels B, Dacquet C, Spedding M, Laudet V. Overview of nomenclature of nuclear receptors. Pharmacol Rev 2006;58:685-704

Ginis I, Luo Y, Miura T, Thies S, Brandenberger R, Gerecht-Nir S, Amit M, Hoke A, Carpenter MK, Itskovitz-Eldor J, Rao MS. Differences between human and mouse embryonic stem cells. Dev Biol 2004;269:360-80

Gofflot F, Chartoire N, Vasseur L, Heikkinen S, Dembele D, Le Merrer J, Auwerx J. Systematic gene expression mapping clusters nuclear receptors according to their function in the brain. Cell 2007;131:405-18

Goncalves MB, Agudo M, Connor S, McMahon S, Minger SL, Maden M, Corcoran JP. Sequential RARbeta and alpha signalling in vivo can induce adult forebrain neural progenitor cells to differentiate into neurons through Shh and FGF signalling pathways. Dev Biol 2009;326:305-13

Gu P, Goodwin B, Chung AC, Xu X, Wheeler DA, Price RR, Galardi C, Peng L, Latour AM, Koller BH, Gossen J, Kliewer $\mathrm{SA}$, Cooney AJ. Orphan nuclear receptor $\mathrm{LRH}-1$ is required to maintain Oct4 expression at the epiblast stage of embryonic development. Mol Cell Biol 2005a;25:3492-505

Gu P, LeMenuet D, Chung AC, Mancini M, Wheeler DA, Cooney AJ. Orphan nuclear receptor GCNF is required for the repression of pluripotency genes during retinoic acid-induced embryonic stem cell differentiation. Mol Cell Biol 2005b;25:8507-19

Gupta P, Ho PC, Huq MM, Ha SG, Park SW, Khan AA, Tsai
NP, Wei LN. Retinoic acid-stimulated sequential phosphorylation, PML recruitment, and SUMOylation of nuclear receptor TR2 to suppress Oct4 expression. Proc Natl Acad Sci USA 2008;105:11424-9

Gupta V, Bhasin S, Guo W, Singh R, Miki R, Chauhan P, Choong K, Tchkonia T, Lebrasseur NK, Flanagan JN, Hamilton JA, Viereck JC, Narula NS, Kirkland JL, Jasuja R. Effects of dihydrotestosterone on differentiation and proliferation of human mesenchymal stem cells and preadipocytes. Mol Cell Endocrinol 2008;296:32-40

Hogan B BR, Costantini F, Lacy E. Manipulating the mouse embryo: a laboratory manual, 1994, New York, Cold Spring Harbor Laboratory Press

Holst D, Luquet S, Kristiansen K, Grimaldi PA. Roles of peroxisome proliferator-activated receptors delta and gamma in myoblast transdifferentiation. Exp Cell Res 2003; 288:168-76

Hu E, Tontonoz P, Spiegelman BM. Transdifferentiation of myoblasts by the adipogenic transcription factors PPAR gamma and C/EBP alpha. Proc Natl Acad Sci USA 1995; 92:9856-60

Jacobs FM, van Erp S, van der Linden AJ, von Oerthel L, Burbach JP, Smidt MP. Pitx3 potentiates Nurr1 in dopamine neuron terminal differentiation through release of SMRT-mediated repression. Development 2009;136:531-40

Jepsen K, Solum D, Zhou T, McEvilly RJ, Kim HJ, Glass CK, Hermanson O, Rosenfeld MG. SMRT-mediated repression of an $\mathrm{H} 3 \mathrm{~K} 27$ demethylase in progression from neural stem cell to neuron. Nature 2007;450:415-9

Kafienah W, Mistry S, Perry MJ, Politopoulou G, Hollander AP. Pharmacological regulation of adult stem cells: chondrogenesis can be induced using a synthetic inhibitor of the retinoic acid receptor. Stem Cells 2007;25:2460-8

Kaji K, Norrby K, Paca A, Mileikovsky M, Mohseni P, Woltjen $\mathrm{K}$. Virus-free induction of pluripotency and subsequent excision of reprogramming factors. Nature 2009;458:771-5

Kiatpongsan S, Sipp D. Medicine. Monitoring and regulating offshore stem cell clinics. Science 2009;323:1564-5

Kim J, Chu J, Shen X, Wang J, Orkin SH. An extended transcriptional network for pluripotency of embryonic stem cells. Cell 2008;132:1049-61

Kim JB, Sebastiano V, Wu G, Arauzo-Bravo MJ, Sasse P, Gentile L, Ko K, Ruau D, Ehrich M, van den Boom D, Meyer J, Hubner K, Bernemann C, Ortmeier C, Zenke M, Fleischmann BK, Zaehres H, Scholer HR. Oct4-induced pluripotency in adult neural stem cells. Cell 2009;136:411-9

Kim M, Habiba A, Doherty JM, Mills JC, Mercer RW, Huettner JE. Regulation of mouse embryonic stem cell neural differentiation by retinoic acid. Dev Biol 2009;328:456-71

Kishi Y, Takahashi J, Koyanagi M, Morizane A, Okamoto Y, Horiguchi S, Tashiro K, Honjo T, Fujii S, Hashimoto N. Estrogen promotes differentiation and survival of dopaminergic neurons derived from human neural stem cells. J Neurosci Res 2005;79:279-86

Kong J, Li YC. Molecular mechanism of 1,25-dihydroxyvitamin D3 inhibition of adipogenesis in 3T3-L1 cells. Am J 
Physiol Endocrinol Metab 2006;290:E916-24

Lau D, Ogbogu U, Taylor B, Stafinski T, Menon D, Caulfield T. Stem cell clinics online: the direct-to-consumer portrayal of stem cell medicine. Cell Stem Cell 2008;3:591-4

Lee CT, Li L, Takamoto N, Martin JF, Demayo FJ, Tsai MJ, Tsai SY. The nuclear orphan receptor COUP-TFII is required for limb and skeletal muscle development. Mol Cell Biol 2004;24:10835-43

Lefterova MI, Lazar MA. New developments in adipogenesis. Trends Endocrinol Metab 2009;20:107-14

Lemkine GF, Raj A, Alfama G, Turque N, Hassani Z, AlegriaPrevot O, Samarut J, Levi G, Demeneix BA. Adult neural stem cell cycling in vivo requires thyroid hormone and its alpha receptor. Faseb J 2005;19:863-5

Li L, Xie X, Qin J, Jeha GS, Saha PK, Yan J, Haueter CM, Chan L, Tsai SY, Tsai MJ. The nuclear orphan receptor COUP-TFII plays an essential role in adipogenesis, glucose homeostasis, and energy metabolism. Cell Metab 2009;9: 77-87

Li W, Sun G, Yang S, Qu Q, Nakashima K, Shi Y. Nuclear receptor TLX regulates cell cycle progression in neural stem cells of the developing brain. Mol Endocrinol 2008;22:56-64

Liu HK, Belz T, Bock D, Takacs A, Wu H, Lichter P, Chai M, Schutz G. The nuclear receptor tailless is required for neurogenesis in the adult subventricular zone. Genes Dev 2008;22:2473-8

Loh YH, Agarwal S, Park IH, Urbach A, Huo H, Heffner GC, Kim K, Miller JD, Ng K, Daley GQ. Generation of induced pluripotent stem cells from human blood. Blood 2009;113: 5476-9

Luo J, Sladek R, Bader JA, Matthyssen A, Rossant J, Giguere V. Placental abnormalities in mouse embryos lacking the orphan nuclear receptor ERR-beta. Nature 1997;388:77882

Mangelsdorf DJ, Thummel C, Beato M, Herrlich P, Schutz G, Umesono K, Blumberg B, Kastner P, Mark M, Chambon P, Evans RM. The nuclear receptor superfamily: the second decade. Cell 1995;83:835-9

Masuyama R, Stockmans I, Torrekens S, Van Looveren R, Maes C, Carmeliet P, Bouillon R, Carmeliet G. Vitamin D receptor in chondrocytes promotes osteoclastogenesis and regulates FGF23 production in osteoblasts. J Clin Invest 2006;116:3150-9

Mayer JL, Klumpers L, Maslam S, de Kloet ER, Joels M, Lucassen PJ. Brief treatment with the glucocorticoid receptor antagonist mifepristone normalises the corticosterone-induced reduction of adult hippocampal neurogenesis. J Neuroendocrinol 2006;18:629-31

Monaghan AP, Grau E, Bock D, Schutz G. The mouse homolog of the orphan nuclear receptor tailless is expressed in the developing forebrain. Development 1995;121:839-53

Monteiro MC, Wdziekonski B, Villageois P, Vernochet C, lehle C, Billon N, Dani C. Commitment of mouse embryonic stem cells to the adipocyte lineage requires retinoic acid receptor beta and active GSK3. Stem Cells Dev 2009; $18: 457-63$
Mullen EM, Gu P, Cooney AJ. Nuclear Receptors in Regulation of Mouse ES Cell Pluripotency and Differentiation. PPAR Res 2007;2007:61563

Niederreither K and Dolle P. Retinoic acid in development: towards an integrated view. Nat Rev Genet 2008;9:541-53

O'Rahilly R BJ, Muller F. [Introduction to the study of embryonic stages in man]. Bull Assoc Anat (Nancy) 1981;65:141-236

Okita K, Ichisaka T, Yamanaka S. Generation of germlinecompetent induced pluripotent stem cells. Nature 2007; 448:313-7

Park IH, Zhao R, West JA, Yabuuchi A, Huo H, Ince TA, Lerou $\mathrm{PH}$, Lensch MW, Daley GQ. Reprogramming of human somatic cells to pluripotency with defined factors. Nature 2008;451:141-6

Park KS, Lee RD, Kang SK, Han SY, Park KL, Yang KH, Song YS, Park HJ, Lee YM, Yun YP, Oh KW, Kim DJ, Yun YW, Hwang SJ, Lee SE, Hong JT. Neuronal differentiation of embryonic midbrain cells by upregulation of peroxisome proliferator-activated receptor-gamma via the JNK-dependent pathway. Exp Cell Res 2004;297:424-33

Park SW, Hu X, Gupta P, Lin YP, Ha SG, Wei LN. SUMOylation of Tr2 orphan receptor involves Pml and fine-tunes Oct4 expression in stem cells. Nat Struct Mol Biol 2007;14:68-75

Perlmann T, Wallen-Mackenzie A. Nurr1, an orphan nuclear receptor with essential functions in developing dopamine cells. Cell Tissue Res 2004;318:45-52

Purton LE, Dworkin S, Olsen GH, Walkley CR, Fabb SA, Collins SJ, Chambon P. RARgamma is critical for maintaining a balance between hematopoietic stem cell self-renewal and differentiation. J Exp Med 2006;203:1283-93

Ross SE, Hemati N, Longo KA, Bennett CN, Lucas PC, Erickson RL, MacDougald OA. Inhibition of adipogenesis by Wnt signaling. Science 2000;289:950-3

Roybon L, Ma Z, Asztely F, Fosum A, Jacobsen SE, Brundin $\mathrm{P}$, Li JY. Failure of transdifferentiation of adult hematopoietic stem cells into neurons. Stem Cells 2006;24:1594-604

Safi R, Muramoto GG, Salter AB, Meadows S, Himburg H, Russell L, Daher P, Doan P, Leibowitz MD, Chao NJ, McDonnell DP, Chute JP. Pharmacological manipulation of the RAR/RXR signaling pathway maintains the repopulating capacity of hematopoietic stem cells in culture. Mol Endocrinol 2009;23:188-201

Sattler U, Samochocki M, Maelicke A, Zechel C. The expression level of the orphan nuclear receptor GCNF (germ cell nuclear factor) is critical for neuronal differentiation. Mol Endocrinol 2004;18:2714-26

Seale P, Bjork B, Yang W, Kajimura S, Chin S, Kuang S, Scime A, Devarakonda S, Conroe HM, Erdjument-Bromage $\mathrm{H}$, Tempst P, Rudnicki MA, Beier DR, Spiegelman BM. PRDM16 controls a brown fat/skeletal muscle switch. Nature 2008;454:961-7

Shang YC, Zhang C, Wang SH, Xiong F, Zhao CP, Peng FN, Feng SW, Yu MJ, Li MS, Zhang YN. Activated beta-catenin induces myogenesis and inhibits adipogenesis in BM-derived mesenchymal stromal cells. Cytotherapy 2007;9:667-81 
Shi Y, Chichung Lie D, Taupin P, Nakashima K, Ray J, Yu RT, Gage FH, Evans RM. Expression and function of orphan nuclear receptor TLX in adult neural stem cells. Nature 2004;427:78-83

Shi Y, Sun G, Zhao C, Stewart R. Neural stem cell self-renewal. Crit Rev Oncol Hematol 2008;65:43-53

Shockley KR, Lazarenko OP, Czernik PJ, Rosen CJ, Churchill GA, Lecka-Czernik B. PPARgamma2 nuclear receptor controls multiple regulatory pathways of osteoblast differentiation from marrow mesenchymal stem cells. J Cell Biochem 2009;106:232-46

Singh R, Artaza JN, Taylor WE, Gonzalez-Cadavid NF, Bhasin S. Androgens stimulate myogenic differentiation and inhibit adipogenesis in C3H 10T1/2 pluripotent cells through an androgen receptor-mediated pathway. Endocrinology 2003;144:5081-8

Singh R, Artaza JN, Taylor WE, Braga M, Yuan X, GonzalezCadavid NF, Bhasin S. Testosterone inhibits adipogenic differentiation in 3T3-L1 cells: nuclear translocation of androgen receptor complex with beta-catenin and T-cell factor 4 may bypass canonical Wnt signaling to down-regulate adipogenic transcription factors. Endocrinology 2006;147: 141-54

Singh R, Bhasin S, Braga M, Artaza JN, Pervin S, Taylor WE, Krishnan V, Sinha SK, Rajavashisth TB, Jasuja R. Regulation of myogenic differentiation by androgens: cross talk between androgen receptor/ beta-catenin and follistatin/transforming growth factor-beta signaling pathways. Endocrinology 2009; 150:1259-68

Stadtfeld M, Brennand K, Hochedlinger K. Reprogramming of pancreatic beta cells into induced pluripotent stem cells. Curr Biol 2008a;18:890-4

Stadtfeld M, Nagaya M, Utikal J, Weir G, Hochedlinger K. Induced pluripotent stem cells generated without viral integration. Science 2008b;322:945-9

Sun C, Nakatake Y, Ura H, Akagi T, Niwa H, Koide H, Yokota T. Stem cell-specific expression of Dax 1 is conferred by STAT3 and Oct $3 / 4$ in embryonic stem cells. Biochem Biophys Res Commun 2008;372:91-6

Sundberg M, Savola S, Hienola A, Korhonen L, Lindholm D. Glucocorticoid hormones decrease proliferation of embryonic neural stem cells through ubiquitin-mediated degradation of cyclin D1. J Neurosci 2006;26:5402-10

Takahashi K, Yamanaka S. Induction of pluripotent stem cells from mouse embryonic and adult fibroblast cultures by defined factors. Cell 2006;126:663-76

Takahashi K, Tanabe K, Ohnuki M, Narita M, Ichisaka T, Tomoda K, Yamanaka S. Induction of pluripotent stem cells from adult human fibroblasts by defined factors. Cell 2007; 131:861-72

Tang W, Zeve D, Suh JM, Bosnakovski D, Kyba M, Hammer RE, Tallquist MD, Graff JM. White fat progenitor cells reside in the adipose vasculature. Science 2008;322:583-6

Tay Y, Zhang J, Thomson AM, Lim B, Rigoutsos I. MicroRNAs to Nanog, Oct4 and Sox2 coding regions modulate embryonic stem cell differentiation. Nature 2008a;455:
1124-8

Tay YM, Tam WL, Ang YS, Gaughwin PM, Yang H, Wang W, Liu R, George J, Ng HH, Perera RJ, Lufkin T, Rigoutsos I, Thomson AM, Lim B. MicroRNA-134 modulates the differentiation of mouse embryonic stem cells, where it causes post-transcriptional attenuation of Nanog and LRH1. Stem Cells 2008b;26:17-29

Teunissen BE, Smeets PJ, Willemsen PH, De Windt LJ, Van der Vusse GJ, Van Bilsen M. Activation of PPARdelta inhibits cardiac fibroblast proliferation and the transdifferentiation into myofibroblasts. Cardiovasc Res 2007;75:519-29

Tomlinson JJ, Boudreau A, Wu D, Atlas E, Hache RJ. Modulation of early human preadipocyte differentiation by glucocorticoids. Endocrinology 2006;147:5284-93

Tontonoz P, Hu E, Graves RA, Budavari Al, Spiegelman BM. mPPAR gamma 2: tissue-specific regulator of an adipocyte enhancer. Genes Dev 1994;8:1224-34

Tremblay GB, Kunath T, Bergeron D, Lapointe L, Champigny C, Bader JA, Rossant J, Giguere V. Diethylstilbestrol regulates trophoblast stem cell differentiation as a ligand of orphan nuclear receptor ERR beta. Genes Dev 2001;15: 833-8

Tsonis PA. 1,25-Dihydroxyvitamin D3 stimulates chondrogenesis of the chick limb bud mesenchymal cells. Dev Biol 1991;143:130-4

van den Berg DL, Zhang W, Yates A, Engelen E, Takacs K, Bezstarosti K, Demmers J, Chambers I, Poot RA. Estrogenrelated receptor beta interacts with Oct4 to positively regulate Nanog gene expression. Mol Cell Biol 2008;28: 5986-95

Wada K, Nakajima A, Katayama K, Kudo C, Shibuya A, Kubota N, Terauchi Y, Tachibana M, Miyoshi H, Kamisaki Y, Mayumi T, Kadowaki T, Blumberg RS. Peroxisome proliferator-activated receptor gamma-mediated regulation of neural stem cell proliferation and differentiation. J Biol Chem 2006;281:12673-81

Wagers AJ, Sherwood RI, Christensen JL, Weissman IL. Little evidence for developmental plasticity of adult hematopoietic stem cells. Science 2002;297:2256-9

Walkey CJ, Spiegelman BM. A functional peroxisome proliferator-activated receptor-gamma ligand-binding domain is not required for adipogenesis. J Biol Chem 2008;283: 24290-4

Wallen-Mackenzie A, Mata de Urquiza A, Petersson S, Rodriguez FJ, Friling S, Wagner J, Ordentlich P, Lengqvist J, Heyman RA, Arenas E, Perlmann T. Nurr1-RXR heterodimers mediate $R X R$ ligand-induced signaling in neuronal cells. Genes Dev 2003;17:3036-47

Wan Y, Chong LW, Evans RM. PPAR-gamma regulates osteoclastogenesis in mice. Nat Med 2007;13:1496-503

Wang J, Rao S, Chu J, Shen X, Levasseur DN, Theunissen TW, Orkin SH. A protein interaction network for pluripotency of embryonic stem cells. Nature 2006;444:364-8

Wang L, Andersson S, Warner M, Gustafsson JA. Morphological abnormalities in the brains of estrogen receptor beta knockout mice. Proc Natl Acad Sci U S A 2001;98:2792-6 
Wang YX, Zhang CL, Yu RT, Cho HK, Nelson MC, Bayuga-Ocampo CR, Ham J, Kang H, Evans RM. Regulation of muscle fiber type and running endurance by PPARdelta. PLoS Biol 2004;2:e294

Woltjen K, Michael IP, Mohseni P, Desai R, Mileikovsky M, Hamalainen R, Cowling R, Wang W, Liu P, Gertsenstein M, Kaji K, Sung HK, Nagy A. piggyBac transposition reprograms fibroblasts to induced pluripotent stem cells. Nature 2009;458:766-70

Xie CQ, Jeong Y, Fu M, Bookout AL, Garcia-Barrio MT, Sun T, Kim BH, Xie Y, Root S, Zhang J, Xu RH, Chen YE, Mangelsdorf DJ. Expression profiling of nuclear receptors in human and mouse embryonic stem cells. Mol Endocrinol 2009;23:724-33

$\mathrm{Xu} \mathrm{J}$, Lamouille $\mathrm{S}$ and Derynck R. TGF-beta-induced epithelial to mesenchymal transition. Cell Res 2009;19: 156-72

Xu Z, Yu S, Hsu CH, Eguchi J and Rosen ED. The orphan nuclear receptor chicken ovalbumin upstream promotertranscription factor II is a critical regulator of adipogenesis.
Proc Natl Acad Sci USA 2008;105:2421-6

Yu J, Hu K, Smuga-Otto K, Tian S, Stewart R, Slukvin, II, Thomson JA. Human induced pluripotent stem cells free of vector and transgene sequences. Science 2009;324: 797-801

Yu YH, Liu BH, Mersmann HJ, Ding ST. Porcine peroxisome proliferator-activated receptor gamma induces transdifferentiation of myocytes into adipocytes. J Anim Sci 2006;84: 2655-65

Zhang CL, Zou Y, He W, Gage FH, Evans RM. A role for adult TLX-positive neural stem cells in learning and behaviour. Nature 2008;451:1004-7

Zhang X, Zhang J, Wang T, Esteban MA, Pei D. Esrrb activates Oct4 transcription and sustains self-renewal and pluripotency in embryonic stem cells. J Biol Chem 2008;283:35825-33

Zhou Q, Chipperfield H, Melton DA, Wong WH. A gene regulatory network in mouse embryonic stem cells. Proc Natl Acad Sci USA 2007;104:16438-43 